\title{
PENGELOLAAN ZAKAT OLEH NEGARA MENYAHUTI GAGASAN REVISI UU ZAKAT NO 38/1999

\author{
(Studi Pemikiran Hukum Islam Indonesia)
}

\author{
Oleh : Nispul Khoiri
}

\begin{abstract}
Abstrak
Adanya dualisme kelembagaan zakat (BAZ-LAZ) sebagai lembaga resmi pengelolaan zakat sebagaimana diimplementasikan UU No 38/1999 tentang Pengelolaan Zakat di Indonesia, dipandang tidak efektif lagi dan mengharuskan UU ini direvisi. Tidak adanya jaminan tergalinya potensi zakat secara maksimal, akuntabilitas dan transparansi yang selalu dipertanyakan, overlapping pendistribusian harta zakat, sinergitas pengentasan kemiskinan yang tidak terukur adalah alasan-alasan mengharuskan pengelolaan zakat harus dilakukan oleh lembaga tunggal yang benar-benar kridibel dalam menggali dana filantropi tersebut. Menjadikan negara sebagai lembaga tunggal dalam pengelolaan zakat adalah alternatif yang tepat, negara sebagai regulator, pengawas dan operator dalam pengelolaan zakat.
\end{abstract}

Kata Kunci: Pengelolaan zakat dan revisi UU zakat

\section{Pendahuluan}

Disyahkannya Undang-Undang (UU) No 38 Tahun 1999 tentang Pengelolaan Zakat di Indonesia yang mulai berlaku pada tanggal 13 Oktober 1999 pantas disyukuri, meskipun UU ini lahir dalam suasana eureforia reformasi 
masa pemerintahan Habibie, namun UU ini banyak memberikan implikasi positif perzakatan di Indonesia. UU Pengelolaan zakat secara yuridis menetapkan adanya proses pengesahan dua lembaga pengelola zakat yakni lembaga dibentuk pemerintah disebut "Badan Amil Zakat" (BAZ) dan lembaga dibentuk oleh masyarakat dikukuhkan pemerintah disebut "Lembaga Amil Zakat" (LAZ). ruang partisipasi masyarakat untuk men-dirikan LAZ begitu terbuka, sehingga LAZ semakin banyak tumbuh dan berkembang turut membantu pemerintah dalam pengentasan kemiskinan. Namun perlu adanya strategi supaya pengelolaan zakat tidak overlapping, basis-basis kemiskinan terdata secara valid, dan harta zakat dapat dipertanggung jawabkan. UU ini menuntut adanya pengelolaan administratif zakat benarbenar terukur, dengan kecakapan SDMyang menguasai bidang-nya, transparan dan akuntabilitas, sehingga manajemen pengelolaan zakat dikelola secara modern dan terukur.

Seiring dalam perjalanannya, tanpa mengurangi apresiasi dan syukur atas disyahkannya UU ini, dalam perkembangannya terus dirasakan banyak kelemahan. UU zakat dipandang tidak mampu lagi memenuhi tuntutan zaman terutama dalam penggalian potensi harta zakat yang begitu besar. Karena itu berbagai desakan muncul, mengharuskan UU ini direvisi. Salah satu materi dipandang urgen untuk direvisi adalah ; mengenai otoritas kelembagaan pengelolaan zakat. Selama ini UU zakat telah mensyahkan dualisme kelembagaan zakat (BAZ-LAZ). Selain adanya lembaga zakat pemerintah (BAZ) juga terbuka ruang pihak swasta mendirikan LAZ. Paradigma ini harus dirobah, pengelolaan zakat harus dikelola lembaga tunggal. Perdebatan yang berlangsung siapakah seharusnya mengurus zakat (amil). Apakah harus ditangani oleh negara atau masyarakat, banyak kalangan menginginkan seharusnya pengelolaan zakat menjadi bagian aktivitas negara. Negara sebagai regulator, pengawas dan operator sebagaimana halnya pajak. Banyak pula kalangan menginginkan pengelolaan zakat diurus pihak swasta lebih akutabilitas dan dipercayai masyarakat.

UUZakat No 38/1999 mengimplentasikan dualisme lembaga pengelola zakat yaitu BAZ-LAZ (Pasal 6, 7, 8, 9 10). Seharusnya lembaga pengelola zakat di negeri ini harus menjadi lembaga tunggal dikelola oleh negara. Negara sebagai regulator, pengawas dan operator. Di berbagai negara (seperti; Malaysia) lembaga zakat dikelola oleh negara. Kemudian tentang sanksi. UU ini terasa mandul, karena tidak memuat sanksi bagi muzakki. Sanski 
hanya dipertegas bagi pengelola zakat (Pasal 21). Agar UU ini mempunyai daya paksa, maka perlu penyempurnaan dengan mencantumkan sanksi muzakki bagi mereka yang enggan membayar zakat ke lembaga. Begitu pula zakat mengurangi pajak. Di Malayia, misalnya; UU zakatnya telah mengatur zakat mengurangi pajak, positifnya bagi masyarakat pajak dan zakat bukan lagi kewajiban rangkap yang membebankan masyarakat, paling tidak revisi UU ini menginginkan zakat mengurangi pajak penghasilan selama ini baru sebatas zakat mengurangi hasil kekayaan kena pajak.

Tulisan ini mencoba mengembangkan pemikiran hukum merekontruksi pemaknaan "amil' (pengurus zakat) dengan mengkolerasikan pemaknaan kenegaraan/pemerintah, yang diulas dalam kajian tafsir dan fiqh, dengan argumentasi logis dan realistik sehingga mengharuskan pengelolaan zakat dilakukan oleh negara.

\section{Terminologi Zakat Dan Negara}

\section{Terminologi Zakat}

Secara bahasa, kata zakat mempunyai beberapa arti yakni; al-barakatu (keberkahan), al-nama' (pertumbuhan dan perkembangan), "at-tharatu" (kesucian) dan "ash-shalahu" (kesucian). ${ }^{1}$ Term zakat disebut juga dengan "sedekah" Al-Mawardi berpendapat term zakat dan sedekah adalah sinonim, redaksinya saja yang berbeda namun pengertian sama. ${ }^{2}$ Secara istilah, zakat adalah ; "Bagian dari harta dengan persyaratan tertentu, yang Allah SWT mewajibkan kepada pemiliknya untuk diserahkan kepada yang berhak menerimanya dengan persyaratan tertentu". ${ }^{3}$

Mazhab Hanafi memberikan pengertian zakat; "Menjadikan sebahagian harta yang khusus dari harta yang khusus sebagai pemilik orang yang khusus, yang ditentukan oleh syariat karena Allah."4 Sedangkan mazhab Syafii

${ }^{1}$ Majma lughah al-Arabiyah, 1972. al-Mu'jam al-Wasith (Mesir;Daar el Ma'arif, Juz 1, hlm. 96.

${ }^{2}$ Al-Mawardi, 1978. al-Ahkam al-Sulthaniyah. Beirut; Daar al-Kutub alIlmiyyah, hlm. 113

${ }^{3}$ Yusuf al-Qaradhawi, 1991. Fiqhus Zakat (Beirut; Muassasah Risalah, hlm. 42.

${ }^{4}$ Wahbah al-Zuhaily, 2000. Zakat Kajian Beberapa Mazha. Bandung; Remaja Rosdakarya, hlm. 84. 
mendefenisikan zakat sebagai; "Sebuah ungkapan keluarnya harta atau tumbuh sesuai dengan cara khusus." ${ }^{5}$ Begitupula mazhab Hanbali memberikan arti; "Zakat ialah hak yang wajib dikeluarkan dari harta yang khusus untuk kelompok yang khusus pula sebagaimana ditetapkan oleh al-Quran."6

Dalam Islam zakat merupakan salah satu dari rukun Islam yang lima. Kewajiban zakat disyariatkan pada tahun ketiga Hijriah. Sebagai rukun Islam yang ketiga setelah syahadat dan shalat, zakat termasuk ibadah yang sudah jelas dan mudah diketahui dalam Islam. Indikatornya terlihat ketika al-Qur'an. menyebutkan zakat sebanyak 30 kali. 27 ayat dalam ayat yang sama disebutkan bersamaan dengan shalat dan 1 ayat disebutkan bersamaan dengan shalat dalam ayat yang berbeda, tetapi pengucapan sama. 2 ayat lain disebutkan tidak bersamaan dengan shalat. Disamping 12 kali perkataan sedekah juga disebutkan dalam al-Quran. ${ }^{7}$ Disamping dalam konteks hadis ditemukan lebih dari 170 hadis. ${ }^{8}$ Semuanya dianalisis dan diulas oleh ahli tafsir maupun ahli hadis. ${ }^{9}$

Penjelasan di atas menunjukkan zakat dipandang sebagai ibadah "maaliyah ijtima'iyah" ibadah memiliki posisi sangat penting, strategis dan menentukan, baik dilihat dari sisi ajaran Islam maupun dari sisi pembangunan kesejahteraan ummat. Melihat kepentingannya pengelolaan zakat erat kaitannya dengan manajemen. Manajemen selalu diartikan pencapaian tujuan organisasi dengan mengemplementasikan empat fungsi dasar; planing, organizing, actuating dan controling dalam menggunakan sumber daya organisasi yang ada. ${ }^{10}$ Apabila dikorelasikan dengan pengelolaan zakat,

${ }^{5}$ Ibid.

${ }^{6}$ Ibid.

${ }^{7}$ Muhammad Fu'ad Abdul Baqi, 1945. al-Mu'jam al-Mufahras Li al-Faz alQuran (Kaherah ; Dar al-Kutub al-Misriyah

${ }^{8}$ Mahmood Zuhdi Abdul Majid, 2003. Pengurusan Zakat. Kuala lumpur; Dawama Sdn. Bhd. hlm, 17.

${ }^{9}$ Ibid., lihat, al-Tabari (M.310.H), Jami' al-Bayan. Al-Jassas (M.370. H), Ahkam al-Quran. Ibn Arabi (M. 543. H), Ahkam al-Quran. Al-Qurtubi (M.774.H), Ahkam al-Quran. Ibn Katsir (M. 774 H), Tafsir al-Quran al-Azim. Pada kitab hadis seperti ; al-Nawawi (M.667 H), Syarh Sahih Muslim. Ibn Hajar al-Asqalani (M. 852 H), Fath al-Barri.

${ }^{10}$ BAZIS PROVINSI DKI JAKARTA \& INSTITUT MANAJEMEN ZAKAT, 2006. Manajemen ZIS BAZIS PROVINSI DKI JAKARTA. Jakarta; BAZIS DKI JAKARTA. hlm. 50 
manajemen zakat adalah adanya pengelolaan zakat yang terencana, terorganisisr, pengawasan yang melekat, sehingga dana zakat dapat dikelola secara baik dan profesional.

\section{Terminologi Negara}

Term negara dipertegas dengan kata kunci; dari kata "staaf" (Bahasa Belanda dan Jerman) "state (bahasa Inggris), "etaf" (bahasa Perancis). ${ }^{11}$ Sedangkan secara istilah, menurut para teoretisi memberikan pengertian beragam sesuai dengan sudut pandang masing-masing karena tidak ada satupun konsep negara yang disepakti bersama ${ }^{12}$ Mariam Budiarjo mendefenisikan negara adalah; "Suatu daerah teritorial yang rakyatnya diperintah oleh sejumlah pejabat (pemerintah) dan yang berhasil menuntut warga negaranya ketaatan pada peraturan perundang-undangan melalui penguasaan kontrol monopolistis dari kekuasaan yang syah." 13 Gramsci, sebagaimana dikutif Azis Thaba, mendefenisikan negara secara luas. "State secara substitusi dibentuk oleh society, dalam kenyataannya, state kemudian memisahkan diri, mendominasi dan mengontrol society. Konsep negara terdiri dari atas lembaga pemerintah (publik institutions) dan aparat pemaksa (coercsion) seperti; meliter, pengadilan, dan lembaga-lembaga hukum, serta lembaga lembaga non pemrintah yang memperoduksi ideologi dan mampu memperkuat hegemoni negara, misalnya keluarga, sekolah dan pers." ${ }^{14}$ Defenisi lain negara sebagai " Pemerintah saja, yaitu lembaga eksekutif dari lembaga pemerintahan, lembaga legislatif, yudikatif, militer dan kepolisian." ${ }^{15}$

Bila dikaitkan teori negara dalam sejarah Islam, Munawir Sjadzali bependapat, Islam tidak memiliki preferensi terhadap sistem politik yang

${ }^{11}$ F. Isjwara, 1980. Pengantar Ilmu Politik. Bandung ; Bina Cipta, hlm. 90

${ }^{12}$ Aminuddin, 1999. Kekuatan Islam dan Pergulatan Kekuasaan di Indo-nesia Sebelum dan Sesudah Runtuhnya Rezim Suharto. Yogyakarta; Pustaka Pelajar. $\mathrm{hlm}$. 19. Apabila posisi negara dihubungkan dengan posisi masyarakat, maka berdasarkan keriteria kemandirian negara, terdapat tiga kelompok teori tentang negara

13 Mariam Budiarjo, 1982. Dasar-Dasar Ilmu Politik. Jakarta; Gramedia. hlm. 40

${ }^{14}$ Abdul Azis Thaba, 1966. Islam dan Negara Dalam Politik Orde Baru . Jakarta; Gema Insani Press. hlm. 48-49.

${ }^{15}$ Aminuddin, op.cit., hlm. 20. 
mapan. Islam tidak mempunyai sistem politik dan hanya memiliki seperangkat tata nilai yang etis yang dapat dijadikan pedoman penyelenggaraan negara. Di dalam al-Quran tidak terdapat pembahasan tentang sistem politik. Begitu pula ketika Nabi wafat, beliau tidak memberikan petunjuk penggantinya dan bagaimana cara memilihnya. Artinya tidak ada dalil, baik qathi' dan zhanni yang memerintah untuk mendirikan negara Islam. ${ }^{16}$ Berbagai upaya ijtihad dilakukan sesudahnya untuk membentuk "negara Islam" ternyata tidak berhasil. Dalam realitanya negara yang dibentuk atas nama Islam hanya digunakan sebagai legitimasi kekuasaan. Dalam hal ini kita tidak dapat mengklaim "negara Islam ideal" secara impiris. ${ }^{17}$

Selama ini teori negara dalam sejarah Islam, bisa muncul dari tiga sumber : (1). Bersumber pada teori khilafah yang dipraktekkan sesudah Rasulullah wafat, terutama biasanya dirujuk pada masa Khulafa al-Rasydin. (2). Bersumber pada teori Imamah dan paham Islam Syiah (3). Bersumber pada teori imarah atau pemerintahan. ${ }^{18}$ Selanjutnya apakah negara harus menganut pola republik atau monarci, apakah sistem pemerintahaanya presidentil atau parlementer, apakah bentuknya kesatuan, federasi atau cukup otonomi luas. Semuanya ini adalah masalah teknis kelembagaan, sebagaimana pernyataan Rasulullah: "Kamu lebih tahu tentang urusan duniamu" (HR. al-Bukhari) artinya masalah duniawi (sekuler) diserahkan kepada masyarakat lebih tahu mana yang cocok dengan tuntunan zamannya. Namun demikian perlu dipertegas bahwa al-Quran dan Sunnah Rasulullah hanya memberikan prinsip-prinsip dasar sebagai dalam bermasyarakat, berbangsa dan bernegara.

Berbagai defenisi negara di atas, penulis cenderung menggunakan pengertian Mariam Budiarjo lebih berelevansi dengan tulisan ini, disamping konteks topik penulisan ini adalah negara Indonesia, namun menginginkan prinsip-prinsip dasar bernegara diajarkan oleh nash (al-Quran-Hadis) harus menjadi bagian penting prinsip dasar kenegaraan Republik Indonesia

${ }^{16}$ Munawir Sjazali, 1990. Islam dan Tata Negara, Ajaran, Sejarah dan Pemikiran. Jakarta; UI Press, hlm. 4-7, 233.

17 Ibid., hlm. 42

${ }^{18}$ Abdul Azis Thaba, op.cit., hlm. 41. 


\section{Pengelolaan Zakat Oleh Negara Pendekatan Historis}

Pensyariatan zakat, tampaknya terlihat dengan upaya pembinaan tatanan sosial yang baru dibangun oleh Nabi Muhammad SAW (di Madinah) sebagai pembangunan ekonomi beroreantasi kerakyatan. ${ }^{19}$ Zakat menjadi instrument kebijakan fiskal ${ }^{20}$ Rasulullah, disamping sebagai sumber pendapatan negara Islam, zakat juga mampu menunjang pengeluaran negara baik dalam government expenditure maupun government transfer, zakat juga mampu mempengaruhi kebijakan ekonomi pemerintah Islam dalam mensejahterakan rakyat. $^{21}$

Melihat peran dan fungsi zakat begitu penting, maka pada masa Rasulullah, Khulafa' al-Rasydin, dan pemerintahan Islam sesudahnya, penge-lolaan zakat menjadi domain negara. Rasulullah telah mengutus Umar Ibn Khattab pergi memungut zakat. Muaz Ibn Djabal di utus ke negeri Yaman. Diantara pegawai-pegawai zakat yang diangkat Rasulullah adalah Ibn Lutaibah, Abu Mas'us, Abu Jahm, Uqbah Ibn Amir, Dahhaq, Ibn Qais dan Ubadah Ibn as-Samit. Rasulullah mengangkat pegawa-pegawai (amilin) mengutus mereka untuk mengumpulkan zakat dan mendistribusikannya kepada yang berhak. Selanjutnya Khalifah Abu Bakar, Khalifah Umar, Khalifah Usman mengikuti apa yang pernah dilakukan Rasulullah. ${ }^{22}$

${ }^{19}$ Selain zakat, ada sejumlah sumber ekonomi ummat yang dibangun Nabi Muhammad SAW. Berdasarkan nash (al-Quran-Hadis) diantaranya adalah; lembaga wakaf, kaffarat, jizyah, ghanimah, dls. Khususnya tentang zakat berbagai ayat begitu tegas dalam pengaturannya, mulai dari penuanaian, muzakki mustahik, manfaat dan ancaman-ancaman bagi yang enggan melak-sanakannya. (Lebih jelas lihat; Qs. at-Taubah : 60. Qs. at-Taubah; 103. Qs. al-Baqarah;267, dls)

${ }^{20}$ Kebijakan fiskal adalah kebijakan yang mempengaruhi pendapatan dan pengeluaran negara. Kebijakan ini bersama kebijakan lain seperti keijakan moneter dan perdagangan bertujuan untuk mempengaruhi kelancaran aktivitas ekonomi. Dalam ekonomi Islam, kebijakan fiskal mempunyai posisi strategis karena kebijakan moneter kurang mendapat prioritas. Nuruddin Muhammad Ali, Zakat Sebagai Instrumen Dalam Kebijakan Fiskal (Jakarta; PT Raja Grafindo Persada: 2006) hlm. xi

\section{${ }^{21}$ Ibid}

22 Sjechul Hadi Permono, 1992. Pemerintah RI Sebagai Pengelola Zakat Jakarta; Pustaka Firdaus, hlm. 3. Lihat juga, Didin Hafidhuddin, 2002. Zakat Dalam Perekonomian Modern (Jakarta : Gema Insani Press, hlm. 125 
Dasar hukum pengelolaan zakat oleh negara didasarkan pada Qs. at-Taubah : 60

Artinya : "Sesungguhnya zakat itu hanyalah untuk orang-orang fakir, orangorang miskin, pengurus-pengurus zakat, para muallaf yang dibujuk hatinya, untuk (memerdekakan) budak, orang yang berutang, untuk jalan Allah, dan orang-orang yang sedang dalam perjalanan, sebagai suatu ketetapan yang diwajibkan Allah dan Allah maha Mengetahui lagi Maha Bijaksana"

Selain ayat di atas, juga pada firman Allah Qs. at-Taubah ; 103:

Artinya : "Ambillah zakat dari sebagian harta mereka, dengan zakat itu kamu membersihkan dan menyucikan mereka dan mendoalah untuk mereka. Sesungguhnya doa kamu itu (menjadi) ketenteraman jiwa bagi mereka. Dan Allah Maha Mendengar Lagi Maha Mengetahui"

Dalam Qs. at-Taubah : 60 tersebut dikemukakan bahwa salah satu golongan yang berhak menerima zakat (mustahik zakat) adalah orangorang yang bertugas mengurus urusan zakat ('amilina 'alaiha). Sedangkan dalam Qs. at-Taubah 103 dijelaskan bahwa zakat itu diambil (dijemput) dari orang-orang yang berkewajiban berzakat (muzakki) untuk kemudian diberikan kepada mereka yang berhak menerimanya (mustahik). Mengambil zakat dan yang menjemput tersebut adalah para petugas (amil).

Menurut al-Qurtubi, ${ }^{23}$ ketika menafsirkan Qs. at-Taubah ; 60 bahwa salah satu golongan yang berhak menerima zakat adalah orang-orang yang bertugas mengurus urusan zakat ('amilina 'alaiha) bahwa amil itu adalah orang-orang yang ditugaskan (diutus oleh Imam/Pemerintah) untuk mengambil, menuliskan menghitung dan mencatatkan zakat dalam manajemen pengelolaan zakat.

Asy-Syaukani menambahkan, zakatharus diserahkan kepada pemerintah, melalui aparatur negara yang disebut al-Quran "al-Amilina 'Alaiha". AlQuran memperhatikan "al-Amilin" dan dimasukkan dalam kelompok mustahik zakat pada urutan ketiga setelah urutan fuqaradan masakin. Hal ini menunjukkan bahwa zakat itu bukanlah satu tugas kewajiban yang diserahkan kepada perseorangan, akan tetapi merupakan tugas kenegaraan. Pemerintah harus

${ }^{23}$ Al-Qurtubi, al-Jami' li Ahkam al-Quran (Beirut Libanon : Daar el Kutub 'Ilmiah, 1413 H/1993 M) Jilid VII-VIII. hlm. 112-113. 
mengurusi, mengawasi dan mengangkat para amil yang mengelola zakat baik sebagai pemungut, penyimpanan, penata buku maupun mendistribusikan zakat. $^{24}$

Diantara dalil hadis yang menunjukkan bahwa pemungutan zakat adalah hak negara berdasarkan hadis Mua'az :

Artinya : "Apabila mereka patuh kepadamu untuk (berikrar dua sahadat) maka beritahukan kepada mereka bahwa Allah mewajibkan zakat kepada mereka pada harta benda mereka, diambil dari orang-orang kaya diantara mereka, lalu dikembalikan kepada yang fakir diantara mereka" 25

Ketika menafsirkan hadis di atas, Ibn Hajar al-Asqalani ${ }^{26}$ mengatakan bahwa kepala negara (Imam) adalah orang yang melaksanakan pemungutan dan pendayagunaan zakat, baik dengan langsung maupun melalui wakilnya. Barang siapa membangkang tidak mengeluarkan zakat, maka zakat diambil secara paksa. Implementasi pentingnya pengelolaan zakat oleh negara, semakin dipertegas oleh asy-Syirazi, ia berpendapat bahwa pemerintah wajib membentuk satu badan yang dinamai "Amalah" yang bertugas untuk urusan zakat. Alasannya adalah : Pertama ; Nabi Muhammad SAW dan Khalifah sesudah beliau turun secara langsung dalam pengelolaan zakat. Kedua; Diantara manusia itu ada yang memiliki harta benda, tetapi tidak mengerti adanya kewajiban pada harta bendanya. Ketiga : Diantara mereka ada yang mengerti, tetapi kikir dan enggan mengeluarkan zakat. ${ }^{27}$

Sejarah telah mencatat, perzakatan pada masa awal pemerintahan Islam telah menjadikan zakat menjadi bagian dari pengelolaan negara. Pemerintah menjadi pelaksana, pengawas dan membuat berbagai kebijakan yang berkaitan dengan perzakatan, karena zakat adalah instrumen dalam kebijakan fiskal memberikan konstribusi besar dalam perbendaharaan negara. Kemunduran pemerintahan muslim (dawlah Islamiyah) mulai terjadi

${ }^{24}$ Muhammad Ali Asy Syaukani.tt, Nailul Authar Syarh Muntaqal Akhbar (Mesir ; al-Mustafa al-Babi al-Halabi Wa Auladuh, Jilid II. hlm .190

${ }^{25}$ Muhammad Ibn Ismail al-Bukhari, tt. Matan Masykul bi Hasyiyatis Sanadi (Mesir ; Dar ihya il-Kutubil, Isa al-Babi al-Halabi. hlm. 242-243

${ }^{26}$ Ibn Hajar al-Asqalani, tt. Fath Barri Syarh Shahih Bukhari. al-Maktabah asSalafiyah. Jilid IV. hlm. 120.

${ }^{27}$ Muhyiddin Abu Bakar Zakariya Yahya Ibn Syaraf an-Nawawi, tt. al-Majmu Syarhul Muhazzab. Mesir, al- Imam. Jilid VI. hlm.167 
ketika zakat terpisah dari kebijakan fiskal negara dan menjadi urusan masingmasing pribadi muslim. Sistem kekhalifahan yang merakyat dan lebih modern diganti dengan sistem monarki. Sumber-sumber pendapatan negara disesuaikan yang dianut oleh kerajaan-kerajaan lainnya terutama dari sektor pajak atau bahkan upeti. Penggunaannya pun juga semakin jauh dari ruh zakat itu sendiri.

\section{Urgensi Zakat Dikelola Oleh Negara}

Dunia perzakatan di Indonesia harus diakui telah mengalami perkembangan yang sangat signifikan, baik dari segi pengumpulan maupun penyaluran. Seiring dengan perkembangan tersebut fakta empiris menyebutkan bahwa pengelolaan zakat harus dilakukan oleh lembaga pemerintahan dibentuk oleh negara, tidak ada dualisme kelembagaan zakat. Negara-lah sebagai regulator, operator, pengawas dalam pengelolaan zakat, sebagaimana tertulis dalam literatur fiqh dan ilmu tafsir term "Amil" (Qs. at-Taubah ; 60) dilakukan oleh "Imam, khalifah atau amir". Hal ini menunjukkan bahwa yang disebut "amil" adalah isnstansi pemerintahan yang bertugas secara khusus dalam pengelolaan perzakatan. ${ }^{28}$ Meskipun pengertian ini dalam perkembangannya mengalami pembiasaan dan bergeser pada figur tokoh keagamaan (di pedesaan) dan lembaga non pemerintah, kepanitiaan mesjid atau kepanitiaan dalam organisasi keagamaan. Mungkin realitas ini kemudian menginsprasikan UU No 38/1999 tentang Pengelolaan Zakat di Indonesia, memberikan ruang partisipasi masyarakat (pihak swasta) terlibat dalam pengelolaan zakat, sehingga terjadi dualisme kelembagaan zakat (BAZ-LAZ) BAZ lembaga yang dibentuk pemerintah sedangkan $L A Z$ lembaga yang dibentuk masyarakat

Peran pemerintah (regulator, operator, pengawas) dalam mengurus zakat justru dirasakan sebagai kebutuhan hukum dalam masyarakat. Paling tidak Ada berbagai pertimbangan logis dan realistis pentingnya negara mengintervensi dalam pengelolaan zakat.

Pertama; Zakat membawa kekuatan imferatif (kewajiban) pemungutannya dapat dipaksakan (Qs. at-Taubah; 9 dan 103). Negara yang mempunyai otoritas untuk melakukan pemaksaaan seperti halnya pajak, karena

${ }^{28}$ Nuruddin Muhammad Ali, op.cit., hlm. 176 
negara mempunyai kekuatan dengan perangkat pemerintahannya, dan didukung regulasi yang mengikat dana zakat akan mudah terkumpulkan, kemudian dapat menjadi bagian pendapatan negara seperti halnya pajak ${ }^{29}$

Kedua; Besarnya jumlah potensi harta zakat yang belum tergali secara maksimal mengharuskan menjadi perhatian negara. Berdasarkan informasi disampaikan oleh Ibu Prof Darmayanti (anggota DPD RI) saat Rapat Dengar Pendapat Umum tentang Pembahasan Revisi UU Zakat No 38/1999, potensi zakat Indonesia hari ini berkisar 19 trilyun pertahun. Sedangkan penerimaan zakat harta dan zakat fitrah secara nasional pada tahun 2009 baru mencapai hanya 1,2 trilyun Bahkan Azyrumardi Azra mengatakan (Harian Republika/September 2010) Potensi zakat (juga infak dan sadakah) Indonesia jelas sangat besar. Tendensi dalam 10 tahun terakhir menunjukkan terus meningkatnya jumlah dana yang terkumpul. Menurut berbagai kajian, kenaikan rata-rata $38,79 \%$ pertahun. Terakhir pada 2009 diperkirakan terkumpul dana zakat sebesar 1,2 trilyun seharusnya ada (27, 2 T untuk 2009). Pada kenyataannya, dana zakat yang berhasil dihimpun dari masyarakat jauh dari potensi yang sebenarnya. Potensi yang besar itu akan dapat dicapai dan disalurkan kalau pelaksanaannya dilakukan oleh negara melalui departemen teknis pelaksana.

Ketiga; Agenda besar dihadapi negara hari ini adalah pengentasan kemiskinan (poverty). Jumlah penduduk miskin/penduduk yang berada di bawah garis kemiskinan di Indonesia pada bulan Maret 2009 sebesar 32,53 juta atau 14,15\%.30. Berdasarkan data dari Kementerian Pembangunan Daerah Tertinggal, dari keseluruhan Kab/kota termasuk daerah tertinggal masih ada sekitar 183 kab/kota dalam kategori daerah tertinggal. ${ }^{31}$ Pengentasan kemiskinan ataupun program kesejahteraan umat tidak cukup dilakukan dengan program APBN/APBD. Potensi dana zakat yang cukup besar tersebut

${ }^{29}$ Zakat bukanlah bentuk charity biasa atau bentuk kedermawan sebagaimana infak, wakaf dan hibah karena zakat bentuk kewajiban yang harus dikeluarkan apabila telah memenuhi nisab dan haul. Sedangkan charity atau donasi dihukumkan sunnah (anjuran). Nuruddin Muhammad Ali, op.cit., hlm xxiv

30 Sumber ;Berita Resmi Statisik, No. 43/07/Th.XII Juli 2009 $d=40724$

${ }^{31}$ Sumber; $h$ ttp://www.ujungpandangekspres.com/indeks.php.option = read\&news- 
sebuah alternatif untuk itu dan akan turut membantu pencapaian sasaran pembangunan nasional.

Keempat, Keadilan menjadi bagian prinsip dasar kenegaraan. Persoalan keadilan dan kesejahteraan umum adalah persoalan struktural yang tidak mungkin terjangkau secara merata tanpa melibatkan negara (indirect giving). Sungguh tepat apa yang dikatakan Masdar Farid Mas'udi ${ }^{32}$; negara selain memiliki kewenangan formal yang mengikat, negara mampu menjangkau berbagai aspek kehidupan masyarakat dalam skala makro. Kualifikasi ini penting, terlebih dalam tatanan masyarakat modern yang semakin terkait secara sistematik dan struktural antara satu unit sosial dan unit sosial lainnya. Dalam tatanan masyarakat yang demikian, ketimpangan sosial yang diderita oleh satu kelompok masyarakat sering kali akar persoalannya terdapat di dalam kelompok masyarakat yang lain. Kemiskinan yang terjadi di desa misalnya, dalam banyak hal bukan semata-mata disebabkan oleh faktor yang melekat pada masyarakat atau sumber daya alam di desa itu semata, melainkan lebih oleh faktor lain yang secara struktural terdapat di dalam masyarakat kota. Oleh karena itu tanpa peranan negara, idealisme zakat untuk menegakkan keadilan sosial dalam kesejahteraan masyarakat Indonesia sulit untu terlaksana.

Kelima; Pengelolaan zakat oleh negara terbangunnya jaringan kerja (net working) lebih terarah, semakin mudah berkoordinasi, komunikasi dan informasi dengan unit pengumpul zakat (LAZ), sehingga pengentasan kemiskinan semakin terarah, tepat guna dan tidak overlapping dalam penyaluran dana zakat, kepastian dan mendisipilinkan muzakki membayar zakat ke lembaga semakin terjamin, sekaligus terbangun konsistensi lembaga pengelola zakat bisa terjaga terus menerus karena sudah ada sistem yang mengatur.

Keenam; Pengelolaan zakat yang dilakukan negara dapat bersinergi dengan semangat otonomi daerah dalam meningkatkan kesejahteraan masyarakat daerah. Peran konkrit PEMDA dalam mekanisme pengelolaan zakat dengan menfasilitasi pembentukan Lembaga Pengelolaan Zakat (LPZ) PEMDA, menetapkan susunan organisasi LPZ sesuai masing-masing daerah, menempatkan aparatur PEMDA sebagai pengurus BAZ, membantu biaya operasional

32 Masdar Farid Mas'udi, Pajak Itu Zakat Uang Allah Untuk Kemaslahatan Rakyat (Jakarta; Mizan Pustaka, 2010) hlm, 131. 
LPZ daerah setiap tahun. Dana zakat yang terkumpul dari daerah didistribusikan kembali kepada daerahnya masing-masing.

Berbagai argumentasi dengan menunjukkan keunggulan zakat dikelola oleh negara di atas, bukan berarti mengecilkan peran partisipasi masyarakat (LAZ) sebagai pihak sewasta dalam pengelolaan zakat, ataupun meragukan manajemen pengelolaan serta tidak mampunya pihak swasta berperan dalam menegakkan keadilan penyaluran zakat. Memang harus diakui dalam euforia reformasi saat ini, kepercayaan rakyat kepada negara semakin memudar, ummat bukannya simpatik kepada BAZ malah menimbulkan antipati, di tengah krisis ketidak percayaan itu peran swasta tampil memikat hati mayarakat. Namun harus disadari, mengutip pendapat Masdar Mas'udi; bahwa ada perbedaan karakteristik antara lembaga negara/pemerintah dan badan-badan swasta pada umumnya. Perbedaan terlihat ; (1). Negara mempunyai otoritas memaksa orang kaya enggan mengeluarkan zakat untuk membayarkan kewajiban sosialnya, dibandingkan dengan lembaga swasta yang tidak mempunyai kekuatan untuk itu. (2). Adanya keterbatasan kemampuan lembaga swasta pada sektor dan wilayah tertentu (3). Dalam kaitannya dengan aspirasi ke adilan publik, lazimnya pengelolaan zakat oleh pihak swasta selalu mengidap penyakit komunalistik, cenderung mementingkan kelompoknya sendiri dan karenanya kurang bisa bersikap adil terhadap semua orang. ${ }^{33}$

Walaupun demikian, bukan berarti secara apriori tanpa reserve seluruh kebijakan perzakatan secara formal dikelola negara. Negara/pemerintah yang lahir dari rakyat, dijalankan atas mandat rakyat, diawasi oleh rakyat dan di atas segalanya ia bekerja untuk kemaslahatan rakyat. Dalam teori "oraganis statis" Alfred Stepan selalu menyebutkan; negara memiliki kemauan dan kepentingan sendiri untuk melakukan intervensi ke dalam kehidupan masyarakat dalam rangka meningkatkan kesejahteraan masyarakat. ${ }^{34}$ Ini adalah prinsip kenegaraan yang sejalan dengan prinsip demokrasi.

Tahir Azhari, ${ }^{35}$ menyebutkan 9 prinsip negara hukum menurut al-

${ }^{33}$ Ibid., hlm. 32.

${ }^{34}$ Abdul Azis Thaba, op.cit., hlm 47

${ }^{35}$ Ibid., 43-44. Bandingkan dengan J. Suyuthi Pulungan, 1994. Fiqh Siyasah, Ajaran, Sejarah dan Pemikiran. Jakarta ; PT Raja Grafindo Persada. hlm. 5-16. 
Quran dan Sunnah Rasulullah sebagai mandat untuk ditegakkan oleh negara yaitu ; Pertama; Prinsip kekuasaan sebagai amanah (Qs. al-Nisa; 58, 149; 13). Kedua; Prinsip musyawarah (Qs. al-Syura; 38, Qs. Ali Imran; 159). Ketiga; Prinsip berkeadilan (Qs. al-Nisa; 135, Qs. al-Maidah; 8, Qs. al-Nahl; 90, Qs. al-An'am; 10). Keempat, Prinsip Persamaan (Qs. at-Taubah ;13). Kelima; Prinsip pengakuan dan perlindungan terhadap hak-hak asasi manusia (Qs. al-Isra'; 70, 17, 33, Qs. al-Maidah ;32, Qs. al-Ghaasyiyah; 21, 22, Qs. Qaaf ; 45, Qs. al-Nisa'; 32). Keenam; Prinsip pengadilan bebas (Dialog Mua'azd dengan Rasulullah diutus negeri Yaman). Ketujuh; Prinsip perdamaian (Qs. al-Baqarah; 194dan 190, Qs. al-Anfal; 61-62). Kedelapan; Prinsipkesejahteraan (Qs. as-Saba'; 15). Kesembilan; Prinsip ketaatan rakyat (Qs. al-Nisa ; 59). Semua prinsip ini juga merupakan prinsip demokrasi. Bahkan dalam Islam, demokrasi yang "di-Islamkan" dengan memberikan landasan substansial "kedaulatan ilahi" yang diamanahkan kepada rakyat ${ }^{36}$

Relevansi prinsip dasar di atas, pada konteks negara dalam pengelolaan zakat. Kapasitas negara/pemerintah adalah sebagai "ulil amr" (pemegang otoritas) yang harus ditaati, namun secara fungsional negara bertindak sebagai amil, ${ }^{37}$ negara tidak saja mengumpulkan harta zakat dari muzakki, tetapi juga mendistribusikan harta zakat tersebut kepada mustahik, negara mengintegrasikan zakat dalam ekonomi dan sosial. Satu sisi pemerintah adalah penguasa tetapi pada sisi lain adalah "administrator" (amil) bagi kepentingan rakyat yang lemah. Apabila dikaitkan kembali dengan pidato pelantikan Abu Bakar sebagai Khalifah pertama, setelah menerima sumpah setia dari rakyatnya (14 abad yang lalu) merupakan komitmen sangat baik mendudukkan peranan pemerintah yang seharusnya. Pidato kenegaraanya menyampaikan : “. ..Aku telah dipilih menjadi pemimpin kalian, sementara aku sadar bahwa aku bukanlah yang terbaik diantara kalian,...... mereka yang lemah diantara kalian bagiku justru adalah pihak yang kuat, sehingga aku kembalikan hak-haknya, sedangkan mereka yang kuat diantara kalian bagiku justru merupakan pihak yang lemah, sehingga aku tuntut mereka kewajibannya....." 38

Atas pandangan ini tidak menjadi soal apakah negara/pemerintahan

\footnotetext{
${ }^{36}$ Abdul Azis Thaba, loc.cit.

${ }^{37}$ Masdar Farid Mas'udi, op.cit., hlm 133.

${ }^{38}$ Ibid.
} 
yang mengurus zakat menyebutnya dirinya sebagai negara agama, negara sekuler atau negara diluar model itu, seperti Indonesia misalnya, esensinya punya komitmen meredistribusi kekayaan melalui harta zakat dalam membangun kesejahteraan dan keadilan bagi masyarakatnya.

Peran lembaga pengelola zakat pihak swasta (LAZ) yang selama ini telah berkiprah, harus diberi otoritas oleh negara, karena mereka turut membantu pemerintah dan masyarakat dalam program pengentasan kemiskinan di Indonesia. Jika negara berperan sebagai regulator, pengawas dan operator dalam pengelolaan zakat, maka keberadaan lembaga zakat pihak swasta harus diakomodir menjadi bagian dari amil negara, atau melebur menjadi bagian lembaga zakat yang dibentuk oleh negara, yang sebelum telah diferivikasi sebagai lembaga zakat swasta untuk diberikan otoritas. Dengan demikian peran negara meredistribusi kekayaan melalui harta zakat dalam membangun kesejahteraan dan keadilan benar-benar dirasakan masyarakat di negeri ini.

\section{Penutup}

Pengelolaan zakat oleh negara, semakin penting dirasakan ketika negara diberikan otoritas sebagai regulator, operator dan pengawas langsung. Mengintegrasikan zakat menjadi domain negara, tidak saja mengembalikan pengelolaan zakat ke khittah awalnya, tetapi peran yan dimainkan negara, mengimplementasikan semangat ajaran zakat sebagai jaminana sosial masyarakat miskin, mendistribusikan keseimbangan harta antara kaya dan miskin dan secara material potensi harta zakat yang tergali secara maksimal menyadarkan rasionalitas redistrubsusi oleh negara menempatkan zakat menjadi bagian pendapatan negara. Namun Akuntabilitas menjadi unsur penting dilakukan oleh pemerintah, harus ada pertanggung jawaban secara transparan. Potensi dana zakat yang begitu besar tidak tertutup kemungkinan mengundang kerawanan berbagai penyimpangan. Artinya kita gagal membuktikan lembaga pengelola zakat pemerintah sebagai institusi publik yang kredibel, konsekwensinya ummat bukannya simpatik malah menimbulkan antipati dan kita mundur kembali ke belakang. 


\section{SUMBER BACAAN}

Al-Mawardi, al-Ahkam al-Sulthaniyah .1978. Beirut; Daar al-Kutub alIlmiyyah

Al-Qurtubi, al-Jami' li Ahkam al-Quran (Beirut Libanon : Daar el Kutub 'Ilmiah, 1413 H/1993 M) Jilid VII-VIII

Abdul Azis Thaba, 1966. Islam dan Negara Dalam Politik Orde Baru. Jakarta ; Gema Insani Press.

Aminuddin, 1999. Kekuatan Islam dan Pergulatan Kekuasaan di Indonesia Sebelum dan Sesudah Runtuhnya Rezim Suharto. Yogyakarta; Pustaka Pelajar.

BAZIS PROVINSI DKI JAKARTA \& INSTITUT MANAJEMEN ZAKAT, 2006. Manajemen ZIS BAZIS PROVINSI DKI JAKARTA (Jakarta; BAZIS DKI JAKARTA

Didin Hafidhuddin, 2002. Zakat Dalam Perekonomian Modern Jakarta : Gema Insani Press

Eri Sudewo, 2004. Manajemen Zakat Tinggalkan 15 Tradisi Tetapkan 4 Prinsip Dasar. Jakarta; Institut Manajemen Zakat. Cet 1.

F. Isjwara, Pengantar Ilmu Politik (Bandung ; Bina Cipta, 1980)

Ibn Hajar al-Asqalani, tt. Fath Barri Syarh Shahih Bukhari. Jilid IV. alMaktabah as-Salafiyah.

J. Suyuthi Pulungan, 1994. Fiqh Siyasah, Ajaran, Sejarah dan Pemikiran. Jakarta ; PT Raja Grafindo Persada.

Masdar Farid Mas'udi,2010. Pajak Itu Zakat Uang Allah Untuk Kemaslahatan Rakyat. Jakarta ; Mizan Pustaka.

Mariam Budiarjo, 1982. Dasar-Dasar Ilmu Politik. Jakarta ; Gramedia. Majma lughah al-Arabiyah, al-Mu'jam al-Wasith. Mesir; Daar el Ma'arif, 1972. Juz 1 
Muhammad Ali Asy Syaukani, tt. Nailul Authar Syarh Muntaqal Akhbar. Jilid II. Mesir ; al-Mustafa al-Babi al-Halabi Wa Auladuh

Muhammad Ibn Ismail al-Bukhari, tt. Matan Masykul bi Hasyiyatis Sanadi. Mesir ; Dar Ihya il-Kutubil, Isa al-Babi al-Halabi.

Mahmood Zuhdi Abdul Majid, 2003. Pengurusan Zakatbid. Kuala lumpur: Dawama Sdn. Bhd.

Muhammad Fu'ad Abdul Baqi, 1945. al-Mu'jam al-Mufahras Li al-Faz al-Quran. Kaherah ; Dar al-Kutub al-Misriyah

Munawir Sjazali, 1990. Islam dan Tata Negara, Ajaran, Sejarah dan Pemikiran. Jakarta; UI Press.

Muhyiddin Abu Bakar Zakariya Yahya Ibn Syaraf an-Nawawi, tt. alMajmu Syarhul Muhazzab. Jilid VI. Mesir, al- Imam..

Media Informasi Pengelola Zakat, 2010. Intrik Politik RUU Zakat di Parlemen. Edisi 5 Th VI Maret April

Nuruddin Muhammad Ali, 2006. Zakat Sebagai Instrumen Dalam Kebijakan Fiskal. Jakarta ; PT Raja Grafindo Persada

Suparman Usman, 2000. Hukum Islam Asas-Asas dan Pengantar Studi Hukum Islam Dalam Tata Hukum Indonesia. Jakarta : Gaya Media Pratama.

Sjechul Hadi Permono, 1992. Pemerintah RI Sebagai Pengelola Zakat. Jakarta: Pustaka Firdaus

Yusuf al-Qaradhawi, 1991. Fiqhus Zakat. Beirut: Muassasah Risalah

UU RI NO 38/1999 Tentang Pengelolaan Zakat di Indonesia

Wahbah al-Zuhaily, 2000. Zakat Kajian Beberapa Mazhab Bandung : Remaja Rosdakarya

Revisi RUU Zakat DPR RI \& Revisi RUU Zakat Usulan Pemerintah (Kemenag $\mathrm{RI})$

Berita Resmi Statisik, No. 43/07/Th.XII Juli 2009

http://www.ujungpandangekspres.com/indeks.php.option=read\&news$d=40724$ 